\title{
Two-way learning in west/east mergers \& acquisitions: Short term and long term viewpoints*
}

\author{
J. Neil Thomson / Peter Mc Namara ${ }^{* *}$
}

This paper reviews the literature in the fields of learning, knowledge creation and storage in organisations and links the theories in these fields to mergers and acquisitions. Specifically, mergers and acquisitions (M\&As) of East German ex-combines by western firms are examined from the viewpoint of does the dominant culture always win or is it possible for two-way learning? The answer to these questions seems to depend upon the mode of acquisition, the level of acculturation and on the length of time elapsed. These three factors and others are combined into a model to predict potential results of $M \& A s$. The theory section is supported by data collected from six western M\&As in East Germany where a total of 36 in-depth, open ended interviews were held.

Dem vorliegenden Artikel wird ein Literaturüberblick zum organisationalen Lernen sowie der Wissenserzeugung und -speicherung von Wissen in Organisationen vorangestellt. Die entsprechenden Theorien werden auf das Spezialthema dieser JEEMS-Ausgabe übertragen. Es werden Übernahmen von ostdeutschen Kombinaten durch westliche Unternehmen untersucht. Folgende Frage steht dabei im Mittelpunkt: Gewinnt immer die dominante Kultur oder ist auch ein wechselseitiges Lernen möglich? Die Art des Zukaufs, der wahrgenommene Grad der Akkulturation und die seit der Übernahme vergangene Zeit scheinen hierauf Einfluß zu haben. Es wird ein Arbeitsmodell entwickelt, um die möglichen Folgen von Unternehmenszusammenschlüssen vorhersagen zu können. Aussagen aus 36 Interviews in sechs untersuchten ostdeutschen Betrieben bekräftigen die theoretischen Vorannahmen.

Manuscript received: 5.7.97; accepted: 1.11.97

** J. Neil Thomson, born 1947, MBA (Cornell), BSc (Bradford) is a PhD student in his fourth year at City University Business School in London. Major areas of research interest are barriers to change and integration in the transformation of East German businesses.

Peter Mc Namara, born 1969, MBS (University College Dublin), BBS in Business Studies (University of Limerick). Currently also a fourth year PhD student at City University Business School London. Main research areas being the management of organisational knowledge and the biotechnology sector.

Mail address: Steinbachweg 39, 69118 Heidelberg, Germany

Tel.: +49 6221809330

Email: Nthomscity@aol.com 


\section{Introduction ${ }^{10}$}

With the fall of the Berlin Wall in 1989 a period of massive social and economic change was ushered into East Germany. The arrival of western owners and managerial systems in East Germany offers a rare opportunity to study radical organisational change within the context of societal upheaval in an advanced but restructuring economy. The context of the research is shaped by well known macro and micro factors which have affected East Germany. At the society level there are the effects of: reunification, monetary union, new legal system, privatisation which included the break up of state combines, and sweeping rises in unemployment. The micro level effects include: Up to $80 \%$ downsizing of work force, competition affecting work intensity and cost awareness, the breakdown of the work group and the rise of individualisation at the work place. All the above elements reflect one commonality for East Germans - a large increase in uncertainty.

\section{Learning and Knowledge in Organisations}

Knowledge has long been recognised as one of the key factors in the creation of economic wealth within societies (Hayek 1945; Marshall 1965; Penrose 1959; Stigler 1968; Teece 1977). An increasing number of authors are coming to view the creation and/or application of knowledge as a key function of the firm (Argyris/ Schon 1978; Grant 1996b; Hamel/ Prahalad 1990; Senge 1993). We can observe that fundamentally different knowledge creation and application strategies were employed by organisations in the East and firms in the West after World War II.

With the collapse of communism these two different forms of knowledge creation and application have come face to face through Mergers and Acquisitions, presenting opportunities and challenges for managers in the field. In this section we will first outline some of the basic elements of knowledge management, including the central issue of creation and deepening of knowledge bases. We will show how knowledge trajectories differed along these two elements in Eastern versus Western firms. We will then outline the opportunities and challenges faced by firms in merging these differing perspectives. The complexity of the task is increased by the fact that knowledge transfer and integration across firms is generally viewed as considerably more difficult than internal creation and application of a firms knowledge base. Core to the transfer and merging of knowledge across firms is acculturation, a theme which forms the centre piece of our empirical analysis which follows in later sections.

10 Partial funding of this research by the Department of Business Administration, University College, Dublin is gratefully acknowledged. 


\subsection{Knowledge Management: Capabilities and Sustainable Competitive Advantage}

We view knowledge management as the process of creation, development, maintenance, expansion, contraction and decline of organisational capabilities. This is both because organisational capabilities are essentially knowledge based and they are the central element in the creation of Sustainable Competitive Advantage (SCA). Organisational capabilities are defined by Amit and Schoemaker (1993) as: information based, tangible, or intangible processes that are firm-specific and are developed over time through complex interactions amongst firms resources .... unlike resource, capabilities are based on developing, carrying and exchanging information through the firm's human capital.

The most important capabilities are core capabilities. They are defined by Teece et al. (1990) as: a set of differential skills, complementary assets, and routines that provide the basis for a firm's competitive capacities and sustainable advantage in a particular business. The development of a core capability is a difficult task which requires the creation of new and novel combinations of a firm's resources and capabilities. As Hamel and Prahalad (1994) note: it may take five, ten, or more years to build a world leadership in a core competence area, consistency of effort is the key. It should be noted here that East and West Germany were separated for over four decades. Within this time their respective producers had the opportunity to create distinctive sets of core competencies.

Sustainable Competitive Advantage (SCA) can be derived from resource or capabilities which are rare, imperfectly imitable, durable, and can be deployed in products and services (Barney 1991; Black/ Boal 1994; Connor 1991; Grant 1991; Hamel/ Prahalad 1990). The goal of SCA is to obtain returns in excess of the resource owners cost of capital. The central source of SCA is core capabilities.

The opposite to core capabilities are core rigidity (Leonard-Barton 1992). They are sets of knowledge which have been valuable sources of competitive advantage in the past but are now inappropriate to the future competitive game. Over time capabilities which have heralded success in the past may no longer offer the route to future success. As the firm seeks to create new capabilities which can produce improved products and services the old capabilities can hamper the effort to develop new ones. We argue in section 2.3 that core rigidities gradually pervaded the majority of East German industry, thus widening the competitive gap between them and the wider market driven world.

\subsection{Learning Races: Assumptions}

Central to our argument are the following set of assumptions. 
The heart of knowledge creation is the individual (Argyris/ Schon 1978; Grant 1996b; Huber 1991; Klein 1989; March 1991; Polanyi 1966; Simon 1991). The task of the firm in knowledge management is the co-ordination of individuals who alone could so not have sufficient knowledge and resource to build the complex products and services required in today's society (e.g. cars) but who combined can efficiently and effectively apply their knowledge to deliver such goods and services (Grant 1996a). The firm appropriates its return in the knowledge management process from its co-ordination of groups of individuals who jointly apply (and to a lesser extent jointly create) knowledge, thus we can see that the heart of knowledge application is the group. The role of the firm necessitates that knowledge creation and application will thus occur in a social environment (Blacker 1995; Nonaka 1994), however the core of knowledge creation will remain the individual.

Unfortunately communism showed a tendency towards intolerance of individuality. Individuality tends to foster mavericks, people who dare to be different, or have a different view of how the world works. Mavericks may take contrary views in the area of what products and services firms should and could produce, a mixture of these are one of the key catalysts to avoid core rigidities (McNamara/ Baden-Fuller 1996). In a communist society it is much less likely that mavericks would have publicly exposed themselves in the workplace. Hence the danger of core rigidities was greater than in a society which tolerates, and in some cases (e.g. USA) embraces maverick behaviour.

Over forty years long there existed a competitive race between East and West across multiple dimensions from sport, to politics, to science and technology. This can be viewed as a learning race, where each society sought to best the other with superior knowledge which could be applied into products and services for all the world to see (e.g. the Space Race, the Arms Race, the Olympics etc.). Some authors argue that the improvements in reliability that investments in learning capabilities bring comes at the price of reduced variability within the firm (Levinthal/ March 1993; March 1991). It is argued that the price of such reduced deviation within the firm is the chance to gain primacy in the competitive race. With lower explicit individual diversity East Germany firms may have sought to increase reliability but at the cost of variability, and hence innovation and learning. Reliability and variability can be seen as a duality or dilemma (Hampden-Turner 1990). The ability to manage these two conflicting pressures to obtain optimum results is a common problem for all organisations.

Improvement in a firm's relative competitive position is affected by the number of competitors in the market and the variability of the strategies to gain success (March 1991). Thus if a firm wishes to maintain its relative position, employment of a learning strategy based around deepening current knowledge will work because it improves reliability. However, in the race for primacy, the 
greater the number of competitors the greater the potential variability of strategies in the market, hence, the greater need for specific firms to encourage variability so that they might hit upon a successful strategy that attains market leadership.

In the West there were many firms with competing strategies, hence creativity bubbled up. The East German system operated as a sort of single entity, GDR PLC if you like. In an environment where there are few firms the best strategy is that of specialisation. In the GDR the outputs of one producer fed into the inputs of another, controlled by political economic plans, rather than the market forces of managerial ingenuity. Whole industries were vertically integrated, while links across industries were fostered by the state. In an ideal world GDR PLC might have been able to greatly increase reliability at the cost of variability. Even then over a period of 45 years separation from the West it would have fallen ever further behind in the learning race, unless it allowed new ideas to filter into its system from the West. It did not generally allow this to happen, nor was the GDR PLC an ideal world - far from it. Based on the above assumptions we argue that ex-GDR firms would on average have much less to offer in a merger with a western firm in terms of strategic or operational creativity.

However, there did exist factors in the ex-GDR which might suggest that on average they could have more to offer in the application of current knowledge in overcoming core rigidities. We will now examine in more detail why these points should be so.

\subsection{Core Rigidities and their Solutions}

The development of core rigidities tends to be path dependent (Cohen/ Levinthal 1990; Collis 1991; Mahoney 1995). The core capability grows over time building on past successes, reinforcing behaviours that have lead to past success and embedding these deeper into the organisation. This enables the firm to refine its organisational routines, procedures and efficiency in knowledge integration. A problem emerges when new capabilities are developed by other firms which more effectively deliver products and services which society wants and is willing to pay for.

In the GDR where whole industries were vertically integrated the development of a core rigidity in one part of the value chain could inhibit the value adding tasks of the entire network. With a policy of full-employment and no real means by which firms could go bankrupt, and thus die, core rigidities could not be removed from the system other than by pro-active management. The problem is that the mechanisms management could employ to remove core rigidities from the firm, were strongly discouraged by the state.

There are good reasons why firms are reluctant to change capabilities without the threat of organisational death. The principle reason is the high switching 
costs which may be involved in moving from one capability to another (Kogut/ Zander 1992). The interplay between bundles of resources and capabilities necessary to create a new core capability will, at the outset, be poorly understood since the creation of organisational knowledge is by definition a complex and uncertain process. Kogut and Zander (1992) articulate this risk in their study when they note that: Switching to new capabilities is difficult as neither the knowledge embedded in the current relationships and principles is well understood, nor the social fabric required to support the new learning known. This can be reinforced by the high levels of inertia within the firm and the high level of costs attached to investments in the exploration of new knowledge (Levinthal/ March 1993; March 1991; Huff et al. 1992). In East Germany the switching costs were very high due to the vertical integration of industries. If for example new production processes in coal production failed, then the knock on effect on electricity production would be considerable, and by extension the consumer production of the region. Switching costs, and the heavy cost of failure on a personal level when challenging the status quo, may have encouraged members of East German combines to continue to apply and expand their current knowledge to the problems the firm faced, rather than developing alternative solutions based on more efficient and effective knowledge bases.

In addressing the challenge of core rigidities the firm is faced with three primary strategies:

First, take a population ecology world view, accepting the onset of organisational decline that core rigidities will eventually cause organisational death as the firm becomes increasingly divorced from its environment. The East German system did not allow bankruptcy, hence this scenario was academic although that is no longer the case.

Second, invest in the promotion of intellectual diversity. Third, invest in unlearning capabilities either provocatively, or as and when the need arises. We will now outline these last two strategies.

\section{3. i. Promotion of Intellectual Diversity - A Solution to Core Rigidities}

The process of exploration for alternative capabilities and organisational strategies is more likely to occur in a firm with differing perspectives on what the purpose of the firm is and what products and services it should deliver. The creation of new organisational knowledge is strongly influenced by the interaction between individual knowledge and the firms knowledge base. The firms knowledge is embedded it its routines, culture, group behaviours and hierarchy. On average the knowledge stored in these systems will be a more accurate reflection of reality than the individual's view. However, organisations are inanimate objects, it is only through the diversity of individuals knowledge that the firm can change its view of the world, and hence its capabilities (March 1991). 
Change is more likely to occur if the firm notices a gap between what its current combination of resources and capabilities can deliver, and what the customer wants over time. When noticing a serious value adding incongruity between market needs and the capabilities of the firm, individuals need to raise questions which highlight these incongruities. Such questions are more likely to come from organisational mavericks, people who have questioning minds, and the desire to express their ideas both to others and though the products and services they create. This is not a typical feature of people who seek to fit into the company or political party line. As such it is unlikely these maverick managers would have lasted long in the old GDR (East Germany).

Another way to promote change in a firm's organisational knowledge is to introduce new people into the firm (Carley 1992; Simon 1992). Personnel turnover can occur when a firm is expanding, hence taking on new people, when people retire from the firm, or alternatively move onto other firms. The idea is that these new people can infuse the firm with new ideas. If they have past experience in another organisation then they can bring insights into alternative ways of running the business, thus enabling the firm to envision new methods of working. In a way this is partially what has occurred in the M\&As of Western and Eastern firms, where new staff have been brought in.

\section{3. ii Unlearning - A Solution to Core Rigidities}

Unlearning is defined by Hedberg (1981) as a process through which learners discard knowledge which is misleading ... This process of unlearning can be equated with Schumpeter's process of creative destruction.

On the knowledge management front new M\&As were offered a work force prepared for unlearning of old capabilities and acceptance of new. They also were also offered a capability at knowledge application which matched, and may have exceeded Western firms. There were reasons some firms over-looked this benefit. In a society were personnel turnover was much higher in the lower ranks, western firms had developed complex systems of organisational routines and procedures which enabled it to preserve its production knowledge. Otherwise the firms knowledge, upon which its capabilities are based, could literally walk out the door as employees moved from one job to the next.

For example in McDonalds there exist very detailed written procedures on the cooking of burgers, how long they can remain on the shelves before being sold or thrown out etc. They are detailed and established rules on the sequential interaction of individuals from the kitchen, to cleaning, to the sales counter. Staff receive on-the-job training into these procedures, reinforced through constant repetition. Such written procedures were less necessary in a GDR restaurant where staff remained in the same workplace, and often the same job, for life. In this environment, sequential interactions between individuals could have been ingrained in staff through organisational culture. 
In a way one could say that organisational culture is a complex routine, embedded in which is the tacit knowledge of the collective organisational mind. One of the difficulties of this type of stored knowledge is that the beliefs and assumptions it generates are hard to clearly identify given that they are subconscious. This can lead to difficulties where these assumptions become removed from the reality of the organisational environment over time, but major decisions continue to be made based upon them. In the GDR the assumptions about the relationship between capital, labour and consumers became increasingly divorced from wider global realities, however the dogma of communism created a world in which broader realities were hidden from the populous.

The surfacing and challenging of these assumptions is possible (Mason/ Mitroff 1981), but real cultural change is a difficult task (Bate 1994). Hence, storage and integration of knowledge by embedding it in the organisational culture can be very efficient when first created, because it passes into the tacit knowledge bases of a wide number of individuals, however, as the environment alters the ability to unlearn such knowledge is a slow, laborious, highly costly, and often unsuccessful crusade (Hax/ Majluf 1984; Wilson 1992). Thus, in the long term storage of large amounts of knowledge within the organisational culture can lead to very inflexible capabilities. Here we see that change in East Germany firms is difficult without a crude removal of culture, as many firms tried via mass redundancies, or a direct inclusion of culture in their Merger and Acquisition strategy. Firms which addressed the issue of acculturation head on were, in our sample, more successful.

\section{Potential Competitive Advantages of CEE M\&As}

We believe there is a very positive potential existing in M\&As in Central and Eastern Europe, which when properly handled can produce competitive advantage. The first area of advantage to be examined builds on the discussion of learning literature in Section 2. The second and related area is the application of current knowledge in the current social context. The third area is a revue of the pros and cons of a developed group culture. Our final area, although there are surely others, is the field of change management.

\subsection{Advantages related to the field of learning - We identify three potential advantages:}

\section{1. i Unlearning}

As discussed in 2c.ii, it has been noted (Bettis/ Prahalad, 1995) that learning in one period is a function of the level of unlearning in the previous period. Unlearning is a process through which learners discard knowledge especially obsolete and misleading knowledge (Hedberg 1981). This process has been 
equated by Imai et al. (1985) with Schumpeter's process of creative destruction. The workers in Eastern and Central Europe have gone through a massive unlearning process with the collapse of command economy structures and ideologies, they can therefore be argued to be ideally poised to produce new knowledge more efficiently than their entrenched western counterparts.

\section{1. ii. Turnover/Intellectual Diversity}

In order for an organisation to learn it needs turnover (Carley 1992; Simon 1991). As up to $80 \%$ of the jobs in ex-combines have been rationalised away, the requirement for personnel turnover is certainly met in CEE M\&As. However, turnover means not just losing positions but also bringing in new blood, the intellectual diversity discussed in section 2 c.i. M\&As, by the very fact that they are often accompanied by middle and top management turnover (Walsh 1988), satisfy this requirement. This is true of all M\&As, not just those with CEE firms, however East German M\&As often saw initial very high management turnover, due to the weeding out of political appointees, usually occupying positions at the highest level.

\section{1. iii Educational standards}

Learning is facilitated by the ability of individuals to grasp concepts. This ability is developed in the schooling system and in this area, specifically in tertiary education and sciences, CEE countries were as advanced if not more so than some of their western neighbours.

\subsection{Application of Current Knowledge and Social Context}

Many authors have noted that a firm's social system plays an important role in the process of learning (Brown/ Duguid 1989; Imai et al. 1985; Kay 1993; Orr 1990; Simon 1991). In deepening the firms current knowledge base managers often focus on changes in the levels of organisational slack and socialisation amongst individuals and groups inside the firm (Blacker 1995; Cyert/ March 1963; Huber 1991; Nonaka/ Takeuchi 1995). To deepen knowledge three vital ingredients are needed: organisational slack, common codes and shared language, and the freedom to experiment. East German firms contained the first two in abundance.

\section{2. i Freedom to experiment:}

New owners of East German firms have the freedom to introduce experiments. In so doing they can combine the new diversity available from the West with a propensity to apply and deepen current knowledge bases. Combined this could lead to a powerful capability to both develop and deepen knowledge into successful commercial products and services. 


\section{2. ii Organisational Slack:}

It is widely recognised that slack permits a higher degree of interaction between people, thus facilitating the transfer of tacit knowledge across individuals (Huber 1991; Nonaka/ Takeuchi 1995). Polanyi (1966) notes that much of which we know cannot be easily communicated. This is tacit knowledge. It is a vital component of our day to day lives. If a capability relies upon tacit knowledge it is more likely to be a source of SCA. This is because the elements that drive the capability forward will be difficult to identify by competitors, and hence copy. If carefully managed organisational slack can foster the transfer of tacit knowledge between individuals and in a merger across organisations.

It is important to initially identify what knowledge is tacitly stored inside the purchased unit. Once this knowledge is identified then it would be important for the M\&A to develop strategies to nurture this knowledge and transfer it across the old organisational boundaries, embedding it in the routines, hierarchy, and culture of the new firm. Instead these firms viewed slack, or overlaps in employees duties and knowledge, as completely surplus to requirements and hence engaged in hasty mass redundancies. This phenomena is not confined to the East, there is anecdotal evidence in the stories of the privatisation of the UK water industry that suggests this many also occur in a long-term member of the western economy.

Organisational slack may not always be used to foster knowledge sharing across individuals with the goal of discovering novel ways of combining the firm's current capabilities and resources to create new and improved products and services. The old GDR seems to be an extreme example of a phenomena observed by the economist Arrow (1974) when he noted that: To a large extent, channels of communication serve purposes other than diffusion of innovations friendship, connivance - and the direction of diffusion may be dictated by factors in addition to profitability. Ghemawat (1991) reinforces Arrow's views by noting that slack needs to be carefully managed if it is not to be appropriated by non-owner stakeholders.

\section{2. iii. Common Codes and Shared Language}

For tacit knowledge to be transferred across individuals there is a need for social proximity and an overlap in task or knowledge bases. These are facilitated by organisational slack. This is not enough. It is necessary for people to be able to efficiently and effectively communicate with each other the knowledge which they wish to share. Shared experiences will offer some common grounds for understanding. A shared language, including culturally bound terms, is also required (Blacker 1995; Cohen/ Levinthal 1990; Pentland/ Rueter 1994). Shared language enables people to express their knowledge in terms the others understand. 
Low personnel turnover, high slack, coupled with high degrees of socialisation inside and outside of work was likely to foster common language. Some combines in the GDR employed whole towns, e.g. Leuna. There was a very high degrees of social interaction between work mates when compared to the average Western firm. All this was likely to give the employees a relatively high degree of shared personal experiences, fostering transfer of tacit knowledge, coupled with a lower need to rely on relatively more inefficient explicit knowledge transfer mechanisms. Within the established group the potential to apply current knowledge bases is likely to have been relatively high, with the right motivational elements. However now with teams completely broken up and many new owners not recognising the need to develop a new common language with their East Germany employees for knowledge to be accessed and employed efficiently, then the opportunity to combine two unique capabilities may have passed. The East's knowledge management capability was in application, created through its high group orientated culture. The West's knowledge management strength was in its diversity of strategies and technology, created through its intellectual diversity, which avoided system wide core rigidities. Combining these knowledge management capabilities with access to new markets, technology, and capital could enable firms to develop a winning SCA.

In entering into a merger with an East German firm we argue that one of the key elements to success is careful management of acculturation. This is because much of the most valuable knowledge and capabilities of East German firms are deeply embedded in their past organisational and societal culture. To successfully tap into these capabilities and leverage them across the new EastWest organisations then it is vital to engage in a process of creating a shared understanding of what the purpose and abilities of the firm is. This cannot be achieved without identifying the tacit knowledge bases of the East and West partners and their relationship to the performance of the firms. And that cannot be done without creation of a common language and organisational slack - both of which require successful acculturation.

\subsection{Group Culture}

Societies to the east of the iron curtain were organised down to the lowest level which was the group. Due to ideological and also control reasons the group was assigned enormous importance. We contend that because of this historical fact, the groundwork for inter-personal communication and trust within teams already existed. We have already noted in section 2 that the creation of knowledge by individuals is not a solitary, but rather a social process (Simon 1991). Teams can be critical in the development of knowledge and thus knowledge based competencies (Carley 1992; Imai et al. 1985; March 1991; Nonaka 1991, 1994). CEE M\&As have workers with proven experience and aptitude of interacting in a group setting. This base is waiting to be exploited, albeit in multi-discipline team not the old production group settings. 
Is there any research linking group culture with organisational effectiveness? Starting with the Hawthorne studies, 1924-1932 - see Mayo (1933), there has been an abundance of significant research on groups that has implications for organisational behaviour and management (Luthans 1992:350). Luthans goes on to summarise this research and its impact on effectiveness.

Table 1: Summary of Research on the Impact That Groups Have on Organisational and Individual Behaviour

\begin{tabular}{|c|c|}
\hline $\begin{array}{l}\text { The Impact of Groups on } \\
\text { Organisational Effectiveness }\end{array}$ & $\begin{array}{c}\text { The Impact of Groups on Individual } \\
\text { Employee Effectiveness }\end{array}$ \\
\hline $\begin{array}{l}\text { Accomplishing tasks that could not be } \\
\text { done by employees themselves }\end{array}$ & $\begin{array}{l}\text { Aiding in learning about the } \\
\text { organisation and its environment }\end{array}$ \\
\hline $\begin{array}{l}\text { Bringing a number of skills and talents } \\
\text { to bear on complex difficult tasks }\end{array}$ & Aiding about learning about oneself \\
\hline $\begin{array}{l}\text { Providing a vehicle for decision } \\
\text { making that permits multiple and } \\
\text { conflicting views to be aired and } \\
\text { considered }\end{array}$ & Providing help in gaining new skills \\
\hline $\begin{array}{l}\text { Providing an efficient means for } \\
\text { organisational control of employee } \\
\text { behaviour }\end{array}$ & $\begin{array}{l}\text { Obtaining valued rewards that are not } \\
\text { attainable by oneself }\end{array}$ \\
\hline $\begin{array}{l}\text { Facilitating changes in organisational } \\
\text { policies or procedures }\end{array}$ & $\begin{array}{l}\text { Satisfying important personal needs, } \\
\text { especially needs for social acceptance } \\
\text { and affiliation }\end{array}$ \\
\hline $\begin{array}{l}\text { creasing organisational stability by } \\
\text { ansmitting shared beliefs and values } \\
\text { new employees }\end{array}$ & \\
\hline
\end{tabular}

Adapted from Nadler et al. (1979), in: Luthans 1992:351

After the Hawthorne Studies further research using controlled experiments into group cohesiveness and the effect of such cohesiveness together with leadership had on productivity were carried out by Schachter et al.. (1951) and Berkowitz (1954). The results indicated, especially in the latter study, that highly cohesive groups which are well lead obtain the highest productivity. Paradoxically cohesive groups which were poorly lead obtained the lowest levels of productivity. Low cohesive groups regardless of leadership quality fell between the two extremes of the cohesive groups. The implications for management being that a group when well handled is a most valuable productive tool, however when mishandled the consequences can be dire. As already noted East German industry was based on the group (Kader) and therefore transformation attempts would seem to have most potential success if the group was maintained 
and given strong leadership. The results of Schachter's work are summarised in diagram format in Figure 1.

Figure 1: The pitchfork results from the Schachter study

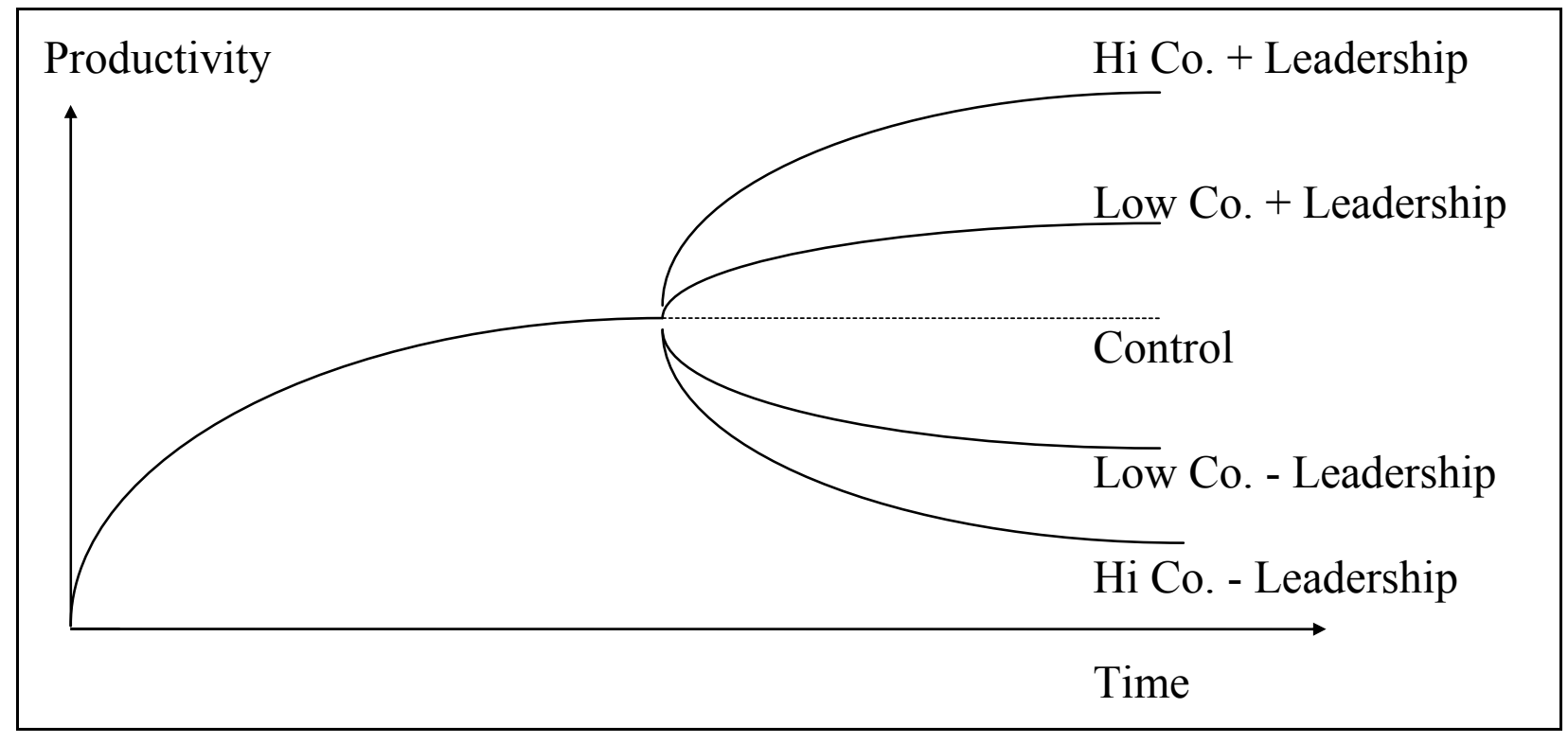

As per Luthans 1992:352

Hi Co. $=$ High level of cohesiveness in the group

Low Co. $=$ Low level of cohesiveness in the group

+ Leadership $=$ positive, strong leadership (induction or influence in Schachter's language)

- Leadership = negative, weak leadership (induction or influence in Schachter's language)

\section{4 Advantages in the field of change management: Crises or catastrophes propagate and force acceptance of radical change}

According to Huff, Huff \& Thomas, 1992, change takes place when stress (the dissatisfaction which signals the need for renewal) overcomes inertia (commitment to current strategy). The idea of change being the outcome of the interaction of forces of stress and inertia is based on the concept of force field analysis from Lewin, 1947. Here change is evolutionary and incremental (Quinn 1978) in nature, so long as the opposing forces are matched and moderate. However with major environmental or internal change forces occurring, stress and inertia will be anything but moderate and will not cancel out. Here change is sudden and revolutionary, Miller \& Friesen (1984) call it a quantum leap. Strebel 1994 created an example of a general model which shows both revolutionary and evolutionary change together but separated by breakpoints.

CEE firms subject to M\&As have been exposed to massive levels of both external (due to the fall of the command economy) and internal (take-over by foreigners) stress. East Germany is probably the most extreme example of abruptness, due to the factors discussed in the introduction. At the other end of 
the spectrum some CEE countries have, until now, experienced levels of stress which have only caused evolutionary change, e.g. Slovenia (Whitley et al. 1997).

To summarise, East German M\&As have experienced massive stress and thus have the potential, if they survive, to successfully accomplish revolutionary change or transformation. It is our thesis that comparable M\&As taking place in western economies have lower levels of stress (especially external) and thus less potential to transform themselves.

\section{Acculturation in Mergers and Acquisitions}

The intermingling of two cultures is called acculturation, a term borrowed from anthropology (Berry 1980). When two firms combine then two cultures do so as well. These cultures can be either national, organisational or as in the case of this study, both. Cross-national M\&As have by definition to combine differing national cultures with varying levels of psychic distance (O'Grady/ Lane 1996) alongside differing firm cultures, a process called double layered acculturation by Barkema et al. (1996). Psychic distance is not synonymous with nationality. O'Grady and Lane (1996:312) extend the normal view of psychic distance as a measure of national cultural divergence to include structural (legal and administrative systems) and language differences as well. There seems to be an appreciable psychic distance between West and East Germans although they both now have common German passports,(see: Lang 1994; Thomson 1996). Because of this inter-German psychic distance paradox, there are inherent difficulties in trying to simplify the measurement of psychic distance in East German acquisitions down to West German and non-West German (foreign) take-overs. Many of the foreign M\&As were negotiated, co-ordinated and operationalised by the West German subsidiary of the mother company. Can such a take-over be then categorised as a foreign purchase? Even if this is the case, does this necessarily mean large psychic distance? Even when no West German subsidiary existed, the foreign firms often hired in West German professional managers to run key areas in the acquired company. There is obviously a continuum of foreignness reflected in psychic distance measurements, running from extremely foreign through to almost West German. Each of the M\&As therefore fits onto a psychic distance continuum reflecting: (a) the number of imported managers - the bigger the number of home country and third country managers, not very prevalent in the sample, the more foreign the classification. More relevant was the number of imported West German managers which reduced the foreigness classification. Latest research (Lang 1997) shows that even though absolute numbers of foreign or West German managers operating in East Germany may be small, they tend to be operating at the highest level and in the most critical areas (finance, marketing, strategy). 
Also in the formula was (b) the influence of any West German subsidiary, both at the time of the M\&A and also at the present.

Even this differentiation between national and organisational cultures does not encompass the whole complexity of foreign M\&As. Very et al. (1996:60) investigated the matter further under the heading of acculturative stress. Acculturative stress being not just the difference between 'what was' before the M\&A and 'what is' afterwards. It occurs when expectations of some proper state of affairs as to 'what ought to be' are not fulfilled (David 1977). Acculturative stress need not be a negative factor, as is well known some sort of stress is necessary for life in general and commercial development in particular. Indeed Very et al. (1996) found that 'to the extent that the buying firm's culture better addresses the acquired firm's normative expectations, differences between the two cultures may sometimes signify sources of acculturative attraction, not stress'. So the forces at work depend upon expectations not necessarily on the reality. Interviews in this research showed again and again that the East German expectations of what western firms could offer in the way of new machinery, equipment, training, technology etc., were utopian. The idea that everything was better and more modern in the west was a typical phenomena of forced isolation and the resultant lack of knowledge. The reality of mass lay-off, disappearance of customers and western managers who proved to be fallible, like all humans, was a shocking realisation (Maaz 1993).

We define acquisitions here as the buying up of enough stock to have control over decision making in the boardroom. This begs the question:

Question 1: In an acquisition when the acquirer (in this case a western firm) is financially and technically strong, will any acculturation takes place on the acquirer's terms?

Mergers are defined here as the sharing of a firm's stock to the extent that decision making at the board level is not effectively in the hands of the acquirer. When however a merger takes place, the power position of the eastern firm is higher.

\section{Question 2: Do mergers mean that there is more opportunity for the eastern culture to influence the incoming western culture, and for learning and information exchange to be two way?}

These two questions will be examined using the model shown in Figure 2. The model contains the mode of combination (merger or acquisition), the type of acculturation and five other forces on the M\&A. The types of acculturation (integration, assimilation, separation and deculturation) are based on Mirvis \& Sales (1984), whilst the model itself is an extension of Nahavandi \& Malekzadeh (1988). 
Figure 2: A model of factors affecting potential success or failure in west/east $M \& A s$

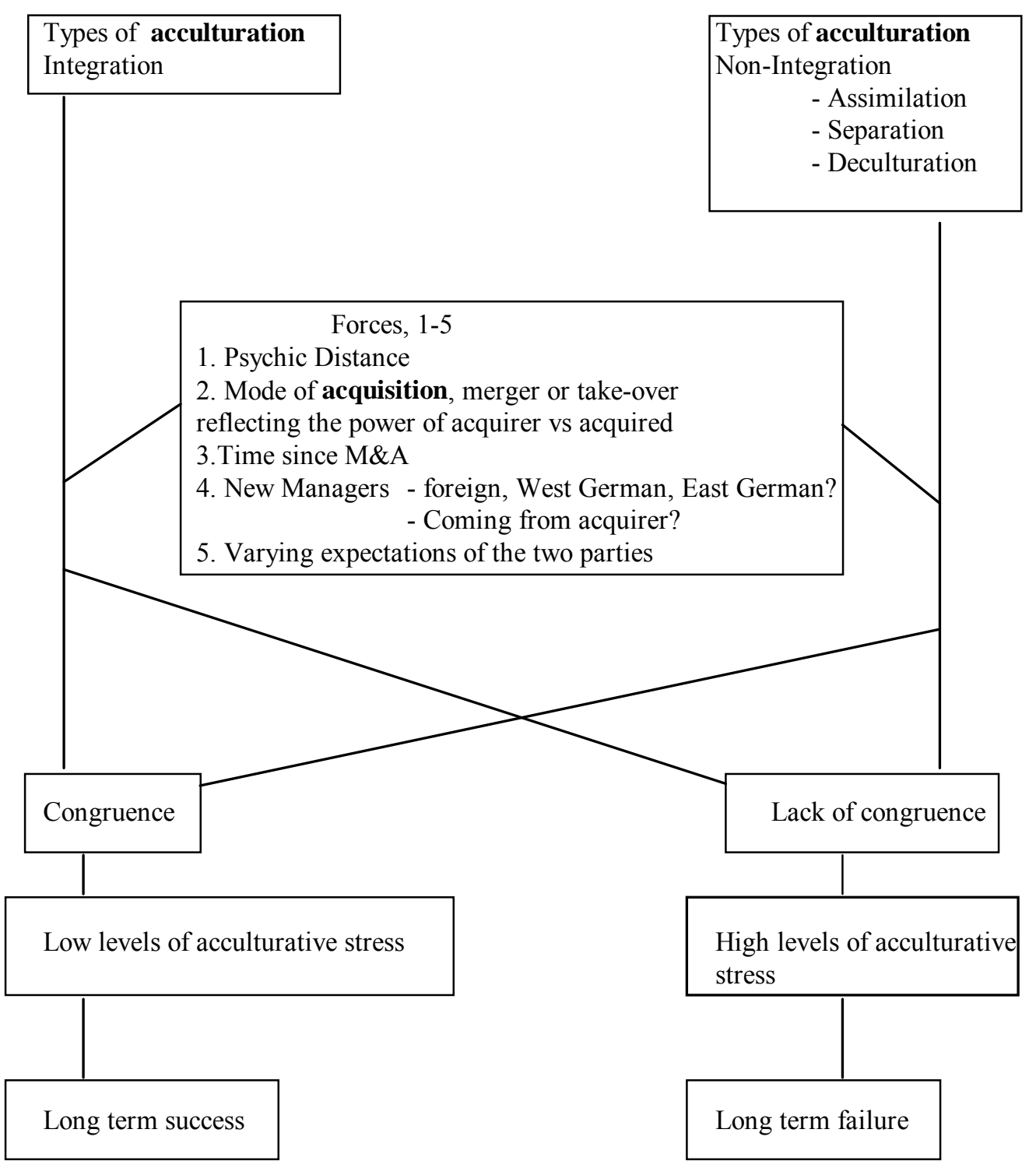

Adopted from that shown in Thomson (1996)

The end stages of the above model need some explanation. What do we mean by success and failure in the long term. Failure is taken here to mean that the firm does not still exists after 5 years and/or has changed the original purchaser. Interestingly enough, using this definition, half of all mergers and take-overs fail, even in a domestic setting (O'Connell 1985). The opposite of failure is success. Success has many definitions depending on whose viewpoint is used. Profits are success for shareholders in neo-classical economics. Continued existence (longevity, see Barkema et al. 1996) and hence employment is success for employees and other stakeholders e.g. local government. 
The aims of this paper are to attempt to gauge the basis for future success, both profits and longevity, by looking at the causes of differences in the intensity of acculturative stress. The higher the intensity of acculturative stress, the less likely is a level of empowerment and shared vision of the remaining original management and workforce upon which future success is dependent. However this future success can also be viewed as time dependent.

It is useful here to revue definitions of short term and long term. The classical economic example of the long term is the time in which it is possible to change the most fixed factor of production, often to build a new factory (Lipsey 1983:223). Under this definition the short term is probably only one year or so and concomitantly the long term anything beyond that. We have taken a more generous definition of long term - the period of time long enough for all the firm's sunk commitments to come to an end (Baumol/ Binder 1991:493). We feel that this definition will increase the short term time span considerably, which is necessary for the conditions existing during our study in East Germany. Commitments made with the privatisation authority (the THA) locked in many new owners of M\&As to certain investment and employment quotas forcing the short term in these cases up to the millennium.

\section{Data collection issues}

The issues in the field of west/east M\&As highlighted above were raised in a series of 36 in-depth, open-ended interviews carried out in 1995-96 in six west/east M\&As in the East Germany. See Table 2 for details. Although the results of such a sample cannot be generalised to East German industry as such, they did show linkages between the literature on learning and knowledge, the level of acculturation and the mode of combination (whether merger or acquisition). Further research on these linkages using a representative sample could check for a wider generalisability both in East Germany and in other transforming economies. As discussed, the M\&As were not chosen to achieve generalisability but it may be worth reviewing some of the research criteria which would have an influence on a study aiming for generalisability. Sector influence: the majority did fall within one sector (services). Due to the deindustrialisation of the ex-GDR, services are now of more importance than manufacturing. Age of the firm: Each firm was privatised within two years of reunification, therefore they were all of a similar age (approximately 5 years since change of ownership). As well as firm age, the age of the interviewees is of importance. There was a marked skewing of the age profile in almost all the firms towards older, but not very old employees. This phenomena occurred due to the social criteria used in downsizing - first in, last out, except where early retirement could be taken. The interviewees' ages reflected the age profile of their firms. Location: all except two were based in the chemical triangle in the South East of the Neue Bundesländer. There are sizeable regional variations in 
the Neue Bundesländer, ranging from an agricultural north, the special capital function in Berlin to areas of former heavy industry in the south. Size: the number of employees varied from 20 up to 2,100, but the core companies were between 50 and 400, i.e. medium sized organisations. Capital intensity: Companies A\&B inherited and expanded a large capital (machinery and plant) infrastructure. All the other firms, with the possible exception of Company F, were mainly made up of offices or laboratories, i.e. low capital values.

Table 2: Foreign M\&As in the Research

- Company A - a large utilities operation, with approximately 2,100 employees. Situated in Saxony and Sachsen-Anhalt.

- Company B - a manufacturer of heavy electrical supply equipment, with approximately 400 employees. Situated in Berlin (East).

- Company $\mathrm{C}$ - in planning and plant assembly within the chemical and water sector, with approximately 50 employees. Situated in Sachsen-Anhalt.

- Company D - in planning and plant assembly within the chemical and water sector, with approximately 240 employees. Situated in Saxony.

- Company E - a research provider in the agricultural industry, with approximately 20 employees. Based in Northern West Germany with only sales and contract production in East Germany.

- Company F - a research provider and also producer of speciality chemicals, with approximately 100 employees. Situated in Saxony.

\section{Actual Data Results}

We return to question 1 posed in Section 4, namely:

In an acquisition when the acquirer (in this case a western firm) is financially and technically strong, will any acculturation takes place on the acquirer's terms?

At the macro (national) level there is much evidence to support this contention. According to a longitudinal study by speech expert Norbert Dittmar (1997) of the Freie Universität Berlin, in cases where West and East Germans used different words for the same object, then the West German words have become the accepted ones, right across the board. 
Table 3: Summary of $M \& A s$

\begin{tabular}{|c|c|c|c|c|c|c|}
\hline Source & $\begin{array}{l}\text { Merger or } \\
\text { Acquisition }\end{array}$ & $\begin{array}{l}\text { Psychic } \\
\text { Distance }\end{array}$ & $\begin{array}{l}\text { New External } \\
\text { Managers }\end{array}$ & $\begin{array}{l}\text { Acculturation } \\
\text { plus } \\
\text { /Sub-Division }\end{array}$ & $\begin{array}{l}\text { Varying ex- } \\
\text { pectation } \\
\text { Differences }\end{array}$ & $\begin{array}{l}\text { Intensity of } \\
\text { Acculturative } \\
\text { Stress }\end{array}$ \\
\hline Company A (US) & Acquisition & $\begin{array}{l}\text { High, no WG } \\
\text { subsidiaries }\end{array}$ & $\begin{array}{l}\text { CEO only US, } \\
\text { rest East } \\
\text { German }\end{array}$ & $\begin{array}{l}\text { Integration/ } \\
\text { Multicultural }\end{array}$ & Large & Medium \\
\hline Company B (GB) & Acquisition & $\begin{array}{l}\text { High, no WG } \\
\text { subsidiaries }\end{array}$ & $\begin{array}{l}\text { Very small } \\
\text { number of } \\
\text { West/East mgrs }\end{array}$ & $\begin{array}{l}\text { Integration/ } \\
\text { Pluralism }\end{array}$ & Not too large & Medium-High \\
\hline $\begin{array}{l}\text { Company C } \\
\text { Sweden }\end{array}$ & Merger & $\begin{array}{l}\text { High, no WG } \\
\text { subsidiaries }\end{array}$ & $\begin{array}{l}\text { At start one } \\
\text { Swede. Now } \\
\text { only East } \\
\text { Germans }\end{array}$ & $\begin{array}{l}\text { Integration/ } \\
\text { Multicultural }\end{array}$ & Low & Low \\
\hline Company D (GB) & Merger & $\begin{array}{l}\text { High, no WG } \\
\text { subsidiaries }\end{array}$ & $\begin{array}{l}\text { One British rest } \\
\text { East German }\end{array}$ & $\begin{array}{l}\text { Integration/ } \\
\text { Multicultural }\end{array}$ & Low & Low \\
\hline Company E (GB) & Acquisition & $\begin{array}{l}\text { Medium, WG } \\
\text { Subsidiary }\end{array}$ & $\begin{array}{l}\text { Several from } \\
\text { West Germany } \\
\text { especially in key } \\
\text { areas }\end{array}$ & $\begin{array}{l}\text { Assimilation/ } \\
\text { Pressure Cooker }\end{array}$ & Not too large & Medium \\
\hline Company F (US) & Merger & $\begin{array}{l}\text { Medium, no WG } \\
\text { subsid. but WG } \\
\text { input }\end{array}$ & $\begin{array}{l}\text { Top managers } \\
\text { from US or WG } \\
\text { via the THA }\end{array}$ & $\begin{array}{l}\text { Rejection/ } \\
\text { Withdrawal }\end{array}$ & Large & High \\
\hline
\end{tabular}


At the micro level of the firm, as researched in this study, the importance of a shared language and common codes across the group has already been dealt with in section 3. Likewise at the micro level our results do not conclusively support the contention in question 1 that acculturation always takes place on the terms of the stronger party. The researched acquisitions showed very quick changes in such areas as technology adaptation, organisation structures, management techniques and the cutting of personnel and groups. Here the differences in speed of changes were dependent upon the culture of the acquiring firm, to use Hofstede's classification (Hofstede 1991), the more masculine the acquirer the quicker the changes. All the acquisitions could be classified as having a medium to a high intensity of acculturative stress. There were however differences due to the usage of Eastern managers (the higher the number, the less radical the changes). Mergers on the other hand, with the exception of Company F, had low intensities of acculturative stress. Mergers showed slower adoption of, and less radical changes in the above technical areas, due to moderating and accepted influence of the eastern managers and culture. Company F turned out to be very different from the other five companies. $25 \%$ of the voting shares stayed in the hands of the privatisation authority, which caused large arguments about strategic direction and investment decisions. These disagreements reflected right through the work force and caused very high acculturative stress. So high indeed that eventually the company was demerged and returned to the privatisation authority. The lesson here seems to be that it is not the variable merger which holds the key to success, rather it is the level of acculturative stress. High stress often reflects an unhappy marriage of interests, whereas low stress points to partners who complement and attract. The other mergers had private sector partners which seemed to preclude some of antagonistic goals experienced by Company $\mathrm{F}$ and its public sector partner.

The results from mergers point towards tentative support for question 2, which was:

\section{Do mergers mean that there is more opportunity for the eastern culture to influence the incoming western culture, and for learning and information exchange to be two way?}

As already mentioned, the presence and importance of Eastern managers seemed to mediate the imposition of radical change. It was reported that the Eastern managers were able to keep some of the existing procedures and structures, thus incubating a feeling of two-way influence as reflected in lower levels of acculturative stress. We noted in section 2 that management had certain options to store and integrate knowledge. Routines are one of these options. We argue that those routines which have been preserved from the past in mergers were accepted and internalised by the work force and as such were excellent vehicles for knowledge storage and integration. The routines and direction imposed by the buyer in acquisitions were not so accepted and internalised. The difference is 
one of agreement/non-agreement with the goals and directives which, according to the learning literature, will show up differing potentials for learning and later in business performance. It should be noted that Question 2 contains an implicit comparison between the different modes of combination, mergers and acquisitions. Interviews in the acquired firms reported more imposed decisions from headquarters, which was reflected in larger expectation differences and acculturative stress levels.

The results are summarised in Table 3 .

\section{Success both immediate and potential}

Do the above results tell us anything about what is proving the best way to do business in a west/east M\&A? The answer seems to depend in part upon the time span of the investigation. Acquisitions have better initial results in so far as they are quicker to adapt to the new environment. However we argue that they have less potential for future success as they have not unlearned and are continuing the western recipes (Grinyer/ Spender 1979) which may not be relevant in the newly forming eastern market economies. The parallel with Schumpeter's dominant logic and Miller's Ikarius Paradox (Miller 1993) is instructional. Mergers have worse initial results, in so far as they are slower to adapt to the new environment, but in our opinion a higher potential for future success. Our faith in their future is based on the perceived democratic integration of the two cultures, reflected in lower levels of acculturative stress. The higher integration in many mergers motivates the eastern workforce to accept new ideas and learn and acquire new knowledge. As already stated the results are not generalisable and need to be checked over time to see if our prognosis of success comes about. Indeed long term studies in East Germany are thin on the ground with the exception of Frese/ Hilligloh (1994).

\section{References}

Amit, R./ Schoemaker, P. (1993): Strategy Assets and Organisational Rent, in: Strategic Management Journal, Vol. 14.

Argyris, C./ Schon, D. (1978): Organisational Learning, Allison-Wesley, Reading, Mass.

Arrow, K. (1962): The Economic Implications of Learning by Doing, in: Review of Economic Studies, Vol. 29, June.

Arrow, K. (1974): Essays in the Theory of Risk-Bearing, Amsterdam, North-Holland Publishing.

Barkema, H.G./ Ball, J.H.J./ Pennings, J.M. (1996): Foreign entry, cultural barriers and learning, in: Strategic Management Journal, Volume 17, pp. 151-166.

Barney, J. (1991): Firm Resources and Sustained Competitive Advantage, in: Journal of Management, Vol. 17, No.1. 
Bate, P. (1994): Strategies for Cultural Change, Oxford, Butterworth Heinemann.

Baumol, W.J./ Binder, A.L. (1991): Economics, principles and policy, San Diego, p.493.

Berkowitz, L. (1954): Group standards, cohesiveness and productivity, in: Human Relations Vol. 7, No. 4, pp. 509-519.

Berry, J.W. (1980), Social \& Cultural Change, in: Triandis, H.C./ Brislin, R.W. (Eds.): Handbook on cross-cultural psychology, Vol. 5, Boston.

Bettis, R./ Prahalad C. (1995): The Dominant Logic: Retrospective and Extension, in: Strategic Management Journal, Vol. 16.

Black, J./ Boal, K. (1994): Strategic Resources: Traits, Configurations and Paths to Sustainable Competitive Advantage, in: Strategic Management Journal, Vol. 15.

Blacker, F. (1995): Knowledge, Knowledge Work and Organisations: An Overview and Interpretation, in: Organisation Studies, Vol. 16, Issue. 6.

Brown, J./ Duguid, P. (1989): Innovation at the Workplace, a Perspective on Organisational Learning, Paper presented at the CMU Conference on Organisational Learning, May.

Carley, K. (1992), Organisational Learning \& Personnel Turnover, in: Organisational Science, Vol. 3., No. 1, Feb.

Cohen, W./ Levinthal, D. (1990): Absorptive Capacity: A New Perspective on Learning and Innovations, in: Administrative Science Quarterly, Vol. 35.

Collis, D. (1991): A Resource Based Analysis of Global Competition: The Analysis of the Global Bearings Industry, in: Strategic Management Journal, Special Issue, Summer.

Connor, K. (1991): A Historical Comparison of Resource-Based Theory and Five Schools of Thought within Industrial Organisation Economics: Do We Have a New Theory of the Firm ?, in: Journal of Management, Vol. 17, No. 1.

Cyert/ March (1963): A Behavioral Theory of the Firm, New Jersey, Prentice Hall International.

David, K. (1977): Epilogue: what shall we mean by changing identities? in: Very et al. (1996).

Dittmar, N. (1997): Die langsame Wende beim sprechen, in: The Berliner Zeitung, 12.03.1997: VI.

Frese/ Hilligloh (1994) in Tromsdorff, G. (Editor): Psychologische Aspekte des soziopolitischen Wandels in Ostdeutschland, de Gruyter Verlag, (1994), Berlin.

Ghemawat, P. (1991): Commitment: The Dynamic of Strategy, New York: The Free Press.

Grant, R. (1991): The Resource-Based Theory of Competitive Advantage: Implications for Strategy Formulation, in: California Management Review, Vol. 33.

Grant, R. (1996a): Prospecting in Dynamically-Competitive Environments: Organisational Capability as Knowledge Integration, in: Organisational Science.

Grant, R. (1996b): Toward a Knowledge Based Theory of the Firm, in: Strategic Management Journal, Vol. 17, Winter Special Issue.

Grinyer, P.H./ Spender J.-C. (1979): Turnaround - Managerial Recipes for Strategic Success, Associated Business Press, London. 
Hamel, G./ Prahalad, C. (1990): The Core Competence of the Corporation, in: Harvard Business Review, May-June.

Hamel, G./ Prahalad, C. (1994): Competing for the Future, Massachusetts, Harvard Business School Press.

Hampden-Turner, C. (1990): Charting the corporate mind: from dilemma to strategy, Basil Blackwell, Oxford.

Hax, A./ Majluf, N. (1984): Strategic Management: An Integrative Perspective, Englewood Cliffs, New Jersey, Prentice Hall Inc.

Hayek, F. (1945): The Use of Knowledge in Society, in: American Economic Review, Vol. 35 No. 4.

Hedberg, B. (1981): How Organisations Learn and Unlearn, in: Nystrom, P./ Starbuck, W. (Eds.): Handbook of Organisational Design, Vol. 1, Oxford University Press, NY.

Hofstede, G. (1991): Cultures \& Organisations: Software of the Mind, McGraw-Hill, London.

Huber, G. (1991): Organisational Learning: The Contributing Processes and the Literature, in: Organisational Science, Vol. 2, No. 1, February.

Huff, J.O./ Huff, A.S./ Thomas, H. (1992): Strategic renewal and the interaction of cumulative stress and inertia, in: Strategic Management Journal, Vol. 13, pp. 55-75.

Imai, K./ Nonaka, I./ Tackeuchi, H. (1985): Managing the New Product Development Process: How Japanese Companies Learn and Unlearn, in: Clark, K./ Hayes, R./ Lorenz, C.: The Uneasy Alliance: Managing the Productivity-Technology Dilemma, Harvard Business Press, Cambridge MA.

Kay, J. (1993): Foundations of Corporate Success: How business strategies add value, Oxford University Press.

Klein, J. (1989): Parenthetic Learning in Organisations: Toward the Unlearning of the Unlearning Model, in: Journal of Management Studies, No. 26, pp. 3, May.

Kogut, B./ Zander, U. (1992): Knowledge of the Firm. Combinative Capabilities and the Replication of Technology, in: Organisation Science, Vol. 3, No. 3, August.

Lang, R. (1994): Führungskräfte in Ostdeutschland: Forschungsbericht zum Projekt SOKULT 92, Arbeitspapier 03, Technische Universität Chemnitz-Zwickau.

Lang, R. (1997): Speech to the opening of the III Ost Forum, Chemnitz, March.

Leonard-Barton, D. (1992): Core Capabilities and Core Rigidities: A Paradox in Managing New Product development, in: Strategic Management Journal, Vol. 13.

Levinthal, D./ March, J. (1993): The Myopia of Learning, in: Strategic Management Journal, Vol. 14.

Lewin, K. (1947): Frontiers in group dynamics, in: Human Relations, No. 1, pp. 5-41.

Luthans, F. (1992): Organizational behavior, Singapore, McGraw-Hill.

Maaz, H.-J. (1993): Das gestürzte Volk, München, Knaur Verlag.

Mahoney, J. (1995): The Management of Resources and the Resource of Management, in: Journal of Business Research, Vol. 33, Management Journal, Vol. 7: 119-140.

March, J. (1991): Exploration and Exploitation in Organisational Learning, in: Organisational Science, Vol. 2, No. 1. 
Marshall, A. (1965): Principles of Economics, London, Macmillan.

Mason, R./ Mitroff, I. (1981): Challenging Strategic Planning Assumptions, New York, Wiley-Interscience, John Wiley and Sons.

Mayo, E. (1933): The human problems of an industrial civilization, London: McMillan.

Mc Namara, P./ Baden-Fuller, C. (1997): Three Traps Facing Knowledge Exploitation in Firms, Eastern Academy of Management Conference Proceedings.

Miller, D./ Friesen, P.H. (1984): Organisations: a quantum view. Prentice Hall, Englewood Cliff, NJ.

Miller, D. (1993): The Architecture of Simplicity, in: Academy of Management Review, Vol. 18, No. 1.

Nadler, D.A./ Hackman, J.R./ Lawler, E.E. (1979): Managing Organizational Behavior, Boston, Mass., Little Brown.

Nelson, R./ Winter, S. (1982): An Evolutionary Theory of Economic Change, Harvard University Press, Mass.

Nonaka, I. (1991): The Knowledge Creating Company, in: Harvard Business Review, November-December.

Nonaka, I. (1994): A Dynamic Theory of Organisational Knowledge Creation, in: Organisational Science, Vol. 5, No. 1, Feb.

Nonaka, I./ Takeuchi, H. (1995): The Knowledge Creating Company, Oxford University Press.

O'Connell, J.M. (1985) in: Business Week: 88-100, cited in: Walsh J.P. (1989): Doing a deal: merger and acquisition negotiations and their impact upon target company top management, in: Strategic Management Journal, Vol 9, pp. 173-183.

O'Grady, S./ Lane, H.W. (1996): The psychic distance paradox., in: Journal of international Business Studies, 2nd Quarter.

Orr, J. (1990): Sharing Knowledge, Celebrating Identity: Community Memory in a Service Culture, in: Middleton, D./ Edwards, D. (Editors): Collective Remembering, Newbury Park, Sage.

Pendler, M./ Burgoyne, J./ Boydell, T. (1991): The Learning Company, McGraw Hill, New York.

Penrose, E. (1959): The Theory of the Growth of the Firm, Basil Blackwell, Oxford.

Pentland, B./ Rueter, H. (1994): Organisational Routines as Grammars of Action, in: Administrative Science Quarterly, 39.

Polanyi, M. (1966): The Tacit Dimension, Routledge Kegan \& Paul Ltd., London.

Quinn, J.B. (1978): Strategic change: logical incrementalism, in: Sloan Management Review, 1, No. 20.

Schachter, S. et al. (1951): An experimental study of cohesiveness and productivity, in: Human Relations, August 1951, pp. 229-239.

Senge, P.M. (1990): The Fifth Discipline: The Art \& Practice of the Learning Organisation, Doubleday, NY. 
Simon, H. (1991): Bounded Rationality and Organisational Learning, in: Organisational Science, Vol. 2.

Stigler, G. (1968): The Economics of Information, in: Stigler, G.: The Organisation of Industry, Homewood, Irwin.

Strebel, P. (1994): Choosing the right change path, in: California Management Review, Winter Edition.

Teece, D. (1977): Technology Transfer by Multinational Firms: The Resource Cost of Transferring Technological Know-How, in: The Economic Journal, Vol. 87.

Teece, D./ Pisano, G./ Schuen, A. (1990): Firm Capabilities, Resources and the Concept of Strategy, Consortium on Competitiveness and Co-operation Working Paper \#90-9, University of California at Berkeley, Centre for Research in Management, Berkeley, CA.

Thomson, J.N. (1996): Take-overs and acculturation: Linkages from East German privatisations to workforce integration, in: Journal of Eastern Europe Management Studies, Vol. 1, No. 4, pp. 25-46.

Very, P./ Lubatkin, M./ Calori, R. (1996): A cross-national assessment of acculturative stress in recent European mergers, in: International Studies of Management and Organisation, Vol. 26, No 1, pp. 59-86.

Walsh, J.P. (1988): Top management turnover following mergers and acquisitions, in: Strategic Management Journal, Vol 9, pp. 173-183.

Whitley, R./ Jacklie, M./ Hocevar, M. (1997): Success without shock therapy in Eastern Europe: The case of Slovenia, WZB Berlin Presentation, Feb.

Wilson D. (1992): A Strategy of Change: Concepts and Controversies in the Management of Change, Routledge, London/ New York. 